\title{
Analisa Pengaruh Jarak Sudu Terhadap Putaran Turbin Ulir Pada Pembangkit Listrik Tenaga Mikro Hidro
}

\author{
I Kadek Agus Ardika ${ }^{1}$, Antonius Ibi Weking ${ }^{2}$, Lie Jasa ${ }^{3}$ \\ [Submission: 09-05-2019, Accepted: 30-06-2019]
}

\begin{abstract}
Turbine is a turbine that has just been studied. The working principle of this turbine screw is based on a screw pump system which functions to lift water from the river to the surface. The turbine screw is basically the return of the screw pump. To obtain an experimental study of the maximum output produced by a PLTMH using a turbine screw, the research is very difficult to apply in real conditions, and problems with screw turbines are made about the effect of blade distance (10 $\mathrm{cm}, 12 \mathrm{~cm}$ and $15 \mathrm{~cm}$ ) on efficiency, voltage, current and power on the MHP using a screw turbine. Therefore the research will use a screw turbine prototype on a laboratory with micro power plants. In this study the best measurement at a distance of $21 \mathrm{~cm}$ blade with an angle of 280 , where the voltage, current, and output power generated by the generator is $\mathbf{1 2 9 . 4}$ Volts loaded with 60 Watt, No load 162.7 Volts, the current generated is 0.1774 Ampere and the power produced is 22.9 Watts. For generator rotation speed that is equal to $7054 \mathrm{rpm}$, while turbine rotation speed generated at pressure is equal to $589 \mathrm{rpm}$ before coupling with generator and $318 \mathrm{rpm}$ after coupling with generator, the efficiency obtained in this PLTMH modeling test is at a distance of $22 \mathrm{~cm}$ blade with angle slope 280 that is equal to $24.5 \%$.
\end{abstract}

Intisari-Turbin Ulir merupakan turbin yang baru diteliti. Prinsip kerja turbin screw ini didasari atas sistem pompa screw yang berfungsi mengangkat air dari sungai menuju permukaan. Turbin screw pada dasarnya merupakan ke balikan dari pompa ulir. Untuk mendapatkan kajian eksperimental hasil output maksimal yang dihasilkan oleh sebuah PLTMH menggunakan turbin screw maka penelitian sangat sulit diterapkan dikondisi riil, dan permasalahan mengenai turbin ulir yang dibuat bagaimana pengaruh jarak sudu $(10 \mathrm{~cm}, 12 \mathrm{~cm}$ dan $15 \mathrm{~cm})$ terhadap efisiensi, tegangan, arusdandaya pada PLTMH dengan menggunakan turbin ulir Oleh sebab itu penelitian akan menggunakan prototype turbin ulir (screw) pada PLTMH bersekala laboratorium. Dalam penelitian ini pengukuran terbaik pada jarak blade $21 \mathrm{~cm}$ dengan kemiringan sudut $28^{\mathbf{0}}$, dimana tegangan, arus, dan daya output yang dihasilkan

\footnotetext{
${ }^{1}$ Mahasiswa,Program Studi Teknik Elektro Fakultas Teknik Universitas Udayana, Linkungan Anyar, Banjar Anyar, Desa Padangsambian, Kecamatan Denpasar Barat, Kota Denpasar, Bali 80361 INDONESIA (tlp: 087753214706; e-mail: ikadekagusardika96@gmail.com )

2, ${ }^{3}$ Dosen, Program Studi Teknik Elektro Fakultas Teknik Universitas Udayana, Jln. Jalan Kampus Bukit Jimbaran 80361 INDONESIA (telp: 0361-703315; fax: 0361-4321; e-mail: tonv@unud.ac.i, ${ }^{3}$ Dosen, lieiasa@unud.ac.id)
}

generator yaitu sebesar 129,4 Volt berbeban 60 Watt, Tanpa beban 162,7 Volt, arus yang dihasilkan 0,1774 Ampere dan Daya yang dihasilkan 22,9 Watt. Untuk kecepatan putaran generator

I Kadek Agus Adika : Analisa Pengaruh Jarak Sudu .... yaitu sebesar 7054 rpm, sedangkan kecepatan putaran turbin yang dihasilkan pada tekanan yaitu sebesar $589 \mathrm{rpm}$ sebelum dikopel dengan generator dan $318 \mathrm{rpm}$ setelah dikopel dengan generator, efisiensi yang diperoleh pada pengujian pemodelan PLTMH ini adalah pada jarak blade $22 \mathrm{~cm}$ dengan kemiringan sudut $28^{0}$ yaitu sebesar $24,5 \%$.

Kata Kunci-PLTMH, , Jarak sudu, Efisiensi, Turbin Ulir

\section{PENDAHULUAN}

Kebutuhan energy listrik di Indonesia saat ini masih didominasi oleh energy yang berbasis bahan bakar fosil, seperti minyak bumi dan batu bara, kerugian bahan bakar adalah sifatnya yang tidak ramah lingkungan. Hasil dari pembakaran bahan bakar fosil adalah $\mathrm{CO}_{2}$ yang merupakan gas rumah kaca dan dapat merusak udara di sekitarnya, karena itu perlu dilakukan penelitian mengenai pemanfaatan potensi sumber-sumber energy terbarukan (Renewable Energy) yang banyak dimiliki oleh Negara kita Indonesia salah satunya adalah aliran sungai dan irigasi [1].

Potensi aliran sungai/ saluran irigasi dapat dibuat pembangkit listrik tenaga mikro hidro (PLTMH). Adapun jenis turbin yang digunakan pada PLTMH salah satunya yaitu turbin ulir [2]. Tubin ulir merupakan turbin yang baru diteliti, prinsip kerja turbin screw ini didasari atas system pompa screw yang berfungsi mengangkat air dari sungai menuju permukaan. Turbin screw pada dasarnya merupakan kebalikan dari pompa ulir, air yang mempunyai head tertentu walaupun dengan debit yang rendah mampu memutar turbin screw yang akan dihubungkan dengan generator untuk menghasilkan listrik [3].

Beberapa peneliti sudah mengembangkan penelitian Archimedian Screw antara lain mengenai optimasi perancangan numeric bentuk geometri ulir [4], menyatakan bahwa rasio kisar optimum bergantung pada jumlah sudu dan rasio radius $\left(R_{1} / R_{0}\right)$ sama dengan 0,54 penelitian dimensi turbin screw yang dibuat menggunakan plat $3 \mathrm{~mm}$ diameter poros screw $20 \mathrm{~cm}\left(\mathrm{R}_{1}\right)$ dan diameter screw $40 \mathrm{~cm}$ atau diameter luar $\left(\mathrm{R}_{0}\right)$, dan turbin screw yang di uji sebanyak 3 turbin screw dengan perbedaan pitch. Jarak pitch yang digunakan adalah $1,6 \mathrm{R}_{0}, 2 \mathrm{R}_{0}$, dan $2,4 \mathrm{R}_{0}$. Sudut kemiringan turbin terhadap aliran debit air atau horizontal sebesar 350. Penelitian selanjutnya pemodelan pembangkit listrik tenaga mikro hidro yang dibangun menggunakan turbin ulir dengan jumlah balde 1 buah dan jumlah Screw turbin sebanyak 10 buah. Dengan sudut head turbin dari dari

$$
\text { p-ISSN:1693 - 2951; e-ISSN: 2503-2372 }
$$


$0^{0}, 10^{0}, 15^{0}, 20^{0}, 25^{0}, 30^{0}, 35^{0}, 40^{0}, 45^{0}, 50^{0}, 55^{0}, 60^{0}$, $70^{\circ}, 80^{\circ}$ dan $90^{\circ}$, dimana efisiensi tertinggi didapat pada sudut $40^{\circ}$ sebesar $14 \%$ [5]. Kemudian penelitian yang dilakukan oleh [6] menghitung kemiringan sudut turbin dan menghitung debit dengan simulator DC.

Berdasarkan permasalahan mengenai turbin ulir yang dimuat dalam latar belakang di atas maka dapat dirumuskan masalah dalam penelitian ini adalah bagaimana pengaruh jarak sudu $(18 \mathrm{~cm}, 22 \mathrm{~cm}$ dan $25 \mathrm{~cm})$ terhadap efisiensi, tegangan, torsi ,arus dan daya pada PLTMH dengan menggunakan turbin ulir Untuk mendapatkan kajian eksperimental hasil output yang dihasilkan oleh sebuah PLTMH menggunakan turbin screw, maka penelitian ini sangat sulit diterapkan dikondisi rill. Oleh sebab itu peneltian akan menggunakan prototype tubin ulir (screw) pada PLTMH bersekala laboratorium dalam penelitian ini akan mengatur jarak sudu pada prototype turbin ulir untuk mengetahui hasil output yang dikeluarkan dari prototype seperti : arus, tegangan, efisiensi, torsi, dan daya. Dalam penelitian ini diharapkan akan didapatkan hasil yang maksimum dari output yang dihasilkan.

\section{DESAIN JARAK SUDU TURBIN ULIR}

\section{A. Prinsip kerja PLTMH dan Turbin Ulir}

Pembangkit Listrik Tenaga Mikrohidro (PLTMH) pada prinsipnya adalah suatu pembangkit listrik skala kecil yang menggunakan tenaga air sebagai tenaga penggeraknya seperti, saluran irigasi, sungai atau air terjun alam dengan cara memanfaatkan tinggi terjunan (head) dan jumlah debit air sebagai sumber tenaga untuk menggerakkan turbin dan memutar generator[7].

Prinsip kerja Turbin Ulir yaitu, air dari ujung atas mengalir masuk ke ruang antara kisar blade screw (bucket) dan keluar dari ujung bawah. Sehingga menimbulkan gaya berat air dan beda tekanan hidrostatik dalam bucket di sepanjang rotor mendorong blade screw dan memutar rotor pada sumbunya, kemudian rotor turbin memutar generator listrik yang disambungkan dengan ujung atas poros turbin ulir [8].

\section{B. Perencanaan Turbin Ulir}

Data yang dapat direncanakan untuk membuat penelitian Turbin Ulir pembangkit listrik tenaga mikro hidro menggunakan tiga prototype turbin yaitu dapat dilihat dalam tabel :

TABELI

DATA PERENCANAAN TURBIN ULIR

\begin{tabular}{|l|l|}
\hline Spesifikasi & Parameter \\
\hline Berat turbin & $20 \mathrm{Kg}$. \\
\hline Panjang turbin & $150 \mathrm{~cm}$ \\
\hline Sudut turbin & $24^{0}, 28^{0}, 31^{0}$ \\
\hline Tebal sudu turbin & $0,25 \mathrm{~cm}$ \\
\hline Tinggi sudu turbin & $10 \mathrm{~cm}$ \\
\hline Jumlah sudu & $9,7,6$ buah sudu \\
\hline Diameter Turbin & $27 \mathrm{~cm}$ \\
\hline Jarak sudu turbin & $18 \mathrm{~cm}, 22 \mathrm{~cm}, 25 \mathrm{~cm}$ \\
\hline
\end{tabular}

C. Desain Turbin Ulir Jarak $18 \mathrm{~cm}$
Desain pemodelan prototipe Turbin Ulir pada pembangkit listrik tenaga mikro hidro yang dirancang dengan jarak antar screw $18 \mathrm{~cm}$, diameter turbin $27 \mathrm{~cm}$, panjang turbin $150 \mathrm{~cm}$, tebal sudu turbin $0,25 \mathrm{~cm}$, dan tinggi sudu $10 \mathrm{~cm}$.

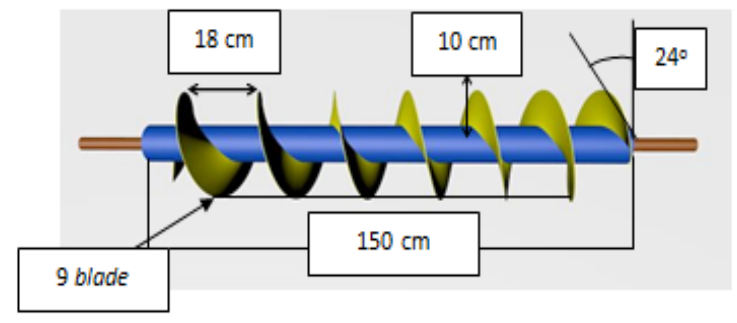

Gambar 1: Turbin Ulir dengan jarak antar Sudu $18 \mathrm{~cm}$

D. Desain Turbin Ulir Jarak Sudu $22 \mathrm{~cm}$

Desain pemodelan prototipe Turbin Ulir pada pembangkit listrik tenaga mikro hidro yang dirancang dengan jarak antar screw $22 \mathrm{~cm}$, diameter turbin $27 \mathrm{~cm}$, panjang turbin $150 \mathrm{~cm}$, tebal sudu turbin $0,25 \mathrm{~cm}$, dan tinggi sudu $10 \mathrm{~cm}$.

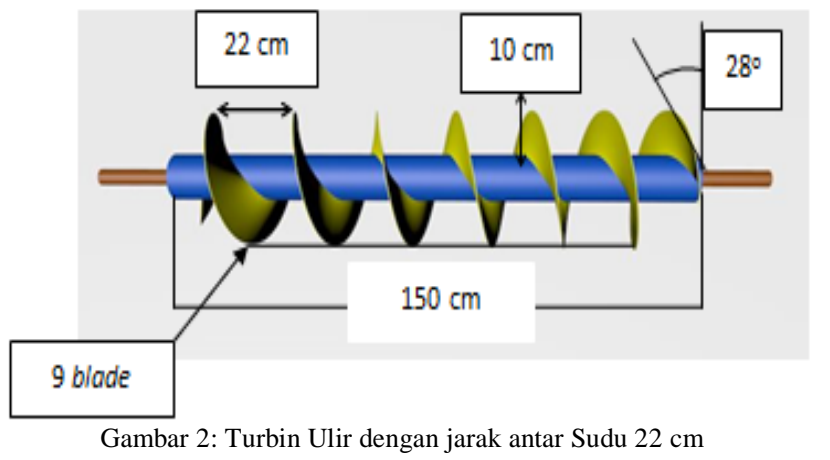

\section{E. Desain Turbin Ulir Jarak Sudu 25}

Desain pemodelan prototipe Turbin Ulir pada pembangkit listrik tenaga mikro hidro yang dirancang dengan jarak antar screw $25 \mathrm{~cm}$, diameter turbin $27 \mathrm{~cm}$, panjang turbin $150 \mathrm{~cm}$, tebal sudu turbin $0,25 \mathrm{~cm}$, dan tinggi sudu $10 \mathrm{~cm}$.

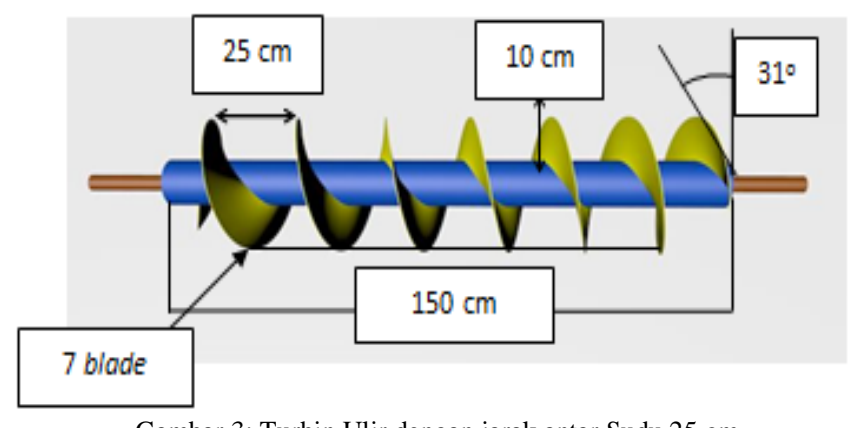

Gambar 3: Turbin Ulir dengan jarak antar Sudu $25 \mathrm{~cm}$

F. Desain Sudu Turbin Ulir pada PLTMH

Desain pemodelan sudu dengan program komputer dapat digambarkan sebagai berikutt : 


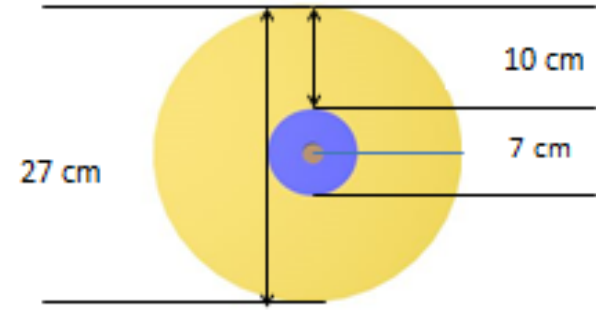

Gambar 4: Sudu Turbin

Terlihat pada gambar sudu turbin ulir pembangkit listrik tenaga mikro hidro dengan diameter lingkaran sudu $27 \mathrm{~cm}$, diameter tititk tengah atau tempat pemasangan di rotor berukuran $7 \mathrm{~cm}$, tebal sudu $0,25 \mathrm{~cm}$.

\section{G. Desain celah Air pada Rumah TurbinPLTMH}

Desain pemodelan celah air sudu dengan program komputer dapat digambarkan sebagai berikutt :

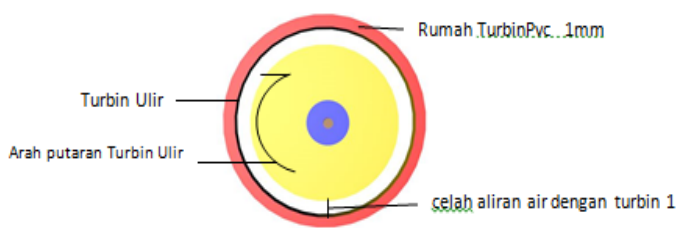

Gambar 5: Jarak celah Air Rumah Turbin terhadap Turbin Ulir.

\section{H. Daya yang dihasilkan Turbin}

Dimana daya yang dihasilkan oleh turbin Archimedes dapat dikur menggunakan persamaan sebagai berikut :

Perhitungan daya hidrolis :

$$
P=\rho \cdot g \cdot Q \cdot h
$$

Dimana :

$$
\begin{aligned}
& \mathrm{P}=\text { Daya hidrolis }(\text { Watt }) \\
& \rho=\text { Massa jenis fluida/air }\left(\mathrm{kg} / \mathrm{m}^{3}\right) \\
& \mathrm{Q}=\text { Debit air }\left(\mathrm{m}^{3} / \mathrm{s}\right) \\
& \mathrm{g}=\text { Gaya gravitasi }\left(\mathrm{m} / \mathrm{s}^{2}\right) \\
& \mathrm{h}=\text { Head atau tinggi air jatuh }(\mathrm{m})
\end{aligned}
$$

Perhitungan Debit dan Tekanan Air

$$
\text { Debit }=\frac{\text { Volume bejana }}{\text { Waktu untuk memenuhi bejana }}
$$

Efisiensi yang dihasilkan Turbin

$$
\eta_{P L T M H}=\frac{P_{G}}{P_{H}} \cdot 100 \%
$$

Dimana :

$\eta_{P L T M H}=$ Efisiensi sistem PLTMH

$P_{G}=$ Daya Generator

$P_{H}=$ Daya Hidrolisis

[9]

I Kadek Agus Adika : Analisa Pengaruh Jarak Sudu ....
Torsi Turbin

$$
\mathrm{T}=\frac{P}{2 n \frac{n}{60}}
$$

Dimana :

$$
\begin{aligned}
& \mathrm{T}=\text { Torsi }(\mathrm{Nm}) \\
& \mathrm{P}=\text { Daya }(\text { Watt }) \\
& \mathrm{n}=\text { kecepatan turbin }
\end{aligned}
$$

Untuk mencari jumlah sudu pada turbin dapat dihitung dengan menggunakan persamaan:

$$
\begin{aligned}
& \mathrm{Z}=\frac{L}{S} \\
& \text { Dimana : } \\
& \mathrm{Z}=\text { Jumlah Ulir } \\
& \mathrm{L}=\text { Panjang Turbin } \\
& \mathrm{S}=\text { Jarak sudu }
\end{aligned}
$$

Jarak sudu (Pitch)

$$
\Lambda=\frac{R 0 . \pi}{\tan \theta}
$$

Dimana :

$$
\begin{aligned}
& \Lambda=\text { Jarak sudu } \\
& R o=\text { Diameter luar sudu dari as } \\
& 2 \text { Л = Jari- jari sudu }
\end{aligned}
$$

Kemiringan sudut

$$
\tan \propto=\frac{R 0 . \pi}{\Lambda}
$$

Dimana :

$$
\begin{aligned}
& \Lambda=\text { Jarak sudu } \\
& R o=\text { Diameter luar sudu dari as } \\
& 2 л=\text { Jari- jari sudu } \\
& \tan \propto=\text { kemiringan sudut blade }
\end{aligned}
$$

\section{METODE PENELITIAN}

Pada penelitian ini pengumpulan data dilakukan dengan beberapa metode yaitu sebagai berikut :

1. Metode eksperimental, metode ini mengujian performansi serta melakukan pengamatan turbin ulir untuk ketinggian head dengan menggunakan tiga buah prototype turbin ulir dengan jarak bladeyang memiliki jarak $18 \mathrm{~cm}, 22 \mathrm{~cm}, 25 \mathrm{~cm}$.

2. Metode Kepustakaan adalah metode pengumpulan data dengan cara mempelajari literature-literatur dari beberapa refrensi dari buku, maupun dari sumber-sumber yang dapat dipertanggung jawabkan.

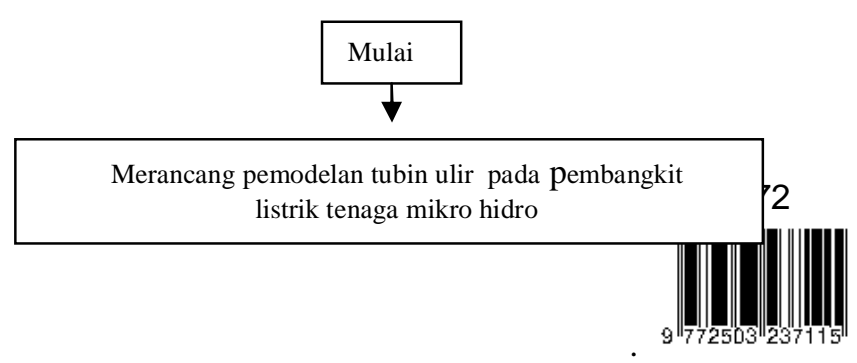




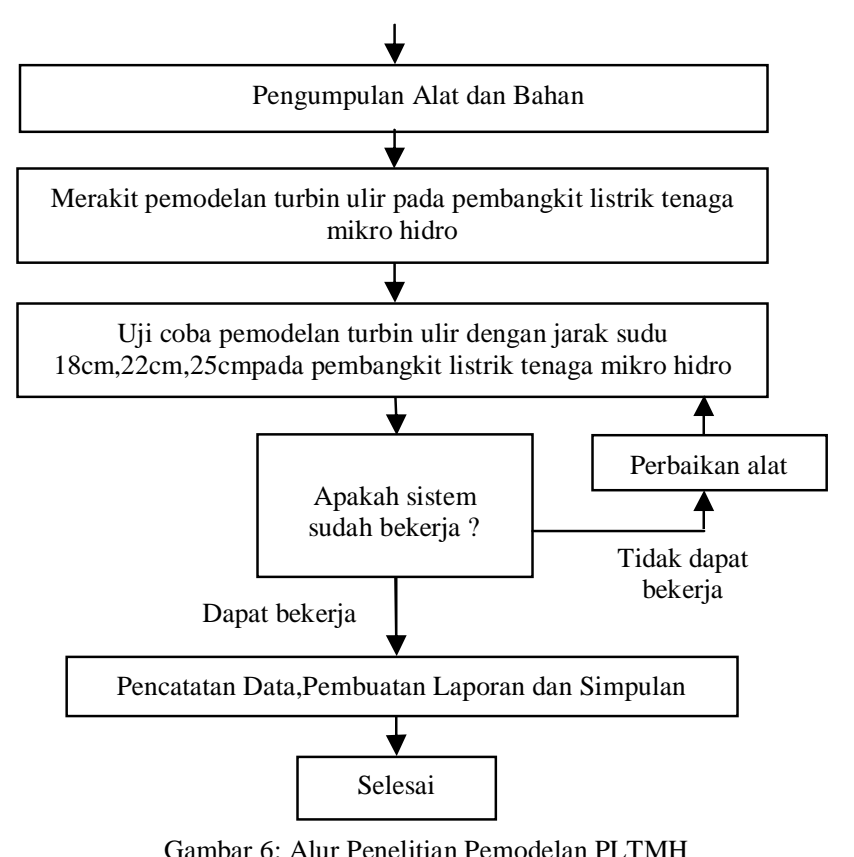

Gambar 6 menunjukan tahapan yang dilakukan pada penelitian ini yaitu mulai dari studi pustaka, merancang model sistem PLTMH, menyiapkan bahan serta peralatan, merakit rancangan pemodelan PLTMH, melakukan pengujian PLTMH, mencatat dan menganalisa data

\section{A. Merancang pemodelan Turbin Ulir}

Desain pemodelan pembangkit listrik tenaga mikro hidro yang sudah dirakitdan di desain mejadi satu dalam program komputer .

\section{B. Mengumpulkan Alat dan Bahan}

Pada proses pengumpulan alat dan bahan, alat - alat yang dipakai dalam penelitian ini seperti obeng (-), (+) , tang kombinasi, kunci pas, alat ukur Multimeter untuk mengukur Arus, Tegangan, Tacho meter untuk mengukur putaran Turbin Ulir dan Kecepatan putaran generator dan, bahan yang digunakan untuk pembuatan prototype yaitu seperti besi untuk rangka protype, akrilik untuk membuat rumah turbin, baut untuk menyatukan rangka dengan rumah turbin .

\section{Merakit Skema Alat Uji}

Proses merakit prototypepemodelan turbin ulir pada pembangkit listrik tenaga mikro hidro dapat dijelaskan sebagai berikut:

1. Merakit turbin ulir dengan generator dan menyatukannya ke posisi yang sudah dibuat pada kerangka.

2. Merakit bak penampungan air dengan pompa air untuk pengaliran air di sertai merakit instalasi pipa.

3. Merakit alat ukur yang akan digunakan untuk mencatat data yang akan dihasilkan dalam pemodelan pembangkit listrik tenaga mikro hidro dengan menggunakan tiga turbin ulir yang berbeda ukuran sudu atau screwnya.

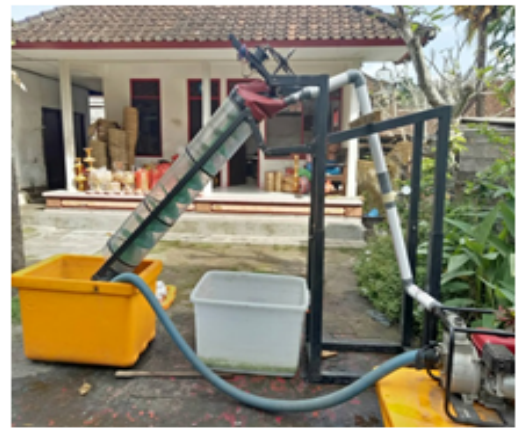

Gambar 7: Realisasi alat Penelitian PLTMH

\section{Proses Uji Coba}

Proses uji coba pemodelan turbin ulir pada pembangkit listrik tenaga mikro hidro dapat dijelaskan sebagai berikut:

1. Menguji debit air yang dikeluarkan oleh bak penampung.

2. Menguji arus dan tegangan yang dikeluarkan generator yang diputar oleh tiap-tiap turbin.

3. Menguji daya generator yang dihasilkan oleh putaran tiaptiap turbin.

4. Menguji kecepatan putaran turbin ulir menggunakan tiga prototype dengan ukuran sudu $\mathrm{cm} 18,22 \mathrm{~cm}, 25 \mathrm{~cm}$. Realisasi turbin Archimedes Screw dibuat menggunakan bahan plat besi. Realisasi dari desain turbin Archimedes Screw dengan diameter turbin $26 \mathrm{~cm}$, lebar turbin $10 \mathrm{~cm}$, dengan jarang blade $17 \mathrm{~cm}, 21 \mathrm{~cm}, 25 \mathrm{~cm}$.

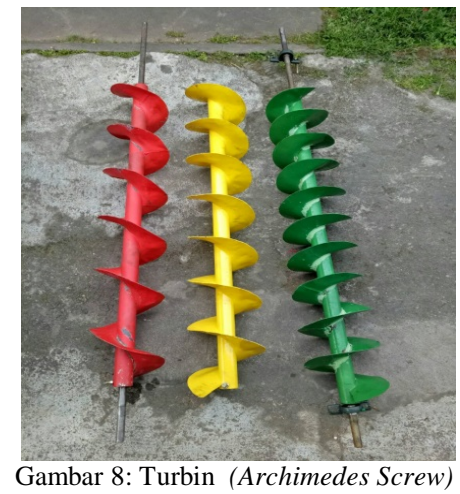

Jika sistem alat tidak bekerja maka dilakukan perbaikan alat setelah dilakukan perbaikan dilakukan uji coba kembali, jika alat sudah sesuaidengan sistem yang di rancang maka dilakukan ke proseses selanjutnya yaitu pencatatan data.

\section{E.Proses Pencatatan Data Pemodelan Turbin Ulir}

Proses pencatatan data pemodelan turbin ulir pada pembangkit listrik tenaga mikro hidro dapat dijelaskan sebagai berikut:

1. Mencatat data putarn tiap-tiap turbin (rpm) dan putaran generator.

2. Mencatat debit air.

3. Mencatat arus dan tegangan output yang dihasilkan generator.

4. Menyusun data-data yang sudah dicatat dan kemudian disusun menjadi laporan. 


\section{IV.HASIL DAN PEMBAHASAN}

\section{A. Pengukuran dan Perhitungan Tekanan Air dan Debit Air}

Pengukuran tekanan air ini bertujuan agar dapat mengetahui pengaruh terhadap putaran turbin, putaran generator, tegangan yang dihasilkan generator, arus yang dihasilkan generator dan daya output yang dihasilkan oleh generator. Adapun alat yang digunakan untuk mengukur tekanan air ini adalah manometer. Untuk nilai tekanan air yang diberikan adalah 24 psi ini merupakan tekanan yang paling baik setelah dilakukan penelitian sebelumnya. Manometer ini dipasang pada pipa pesat tempat air mengalir menuju turbin.

Pada pengukuran debit air menggunakan metode penampungan air, dalam mengukur debit air menggunakan bak atau box penampungan air yang berkapasitas 220 liter. Pengukuran debit air ini disesuaikan dengan pengaturan tekanan air yang diberikan. Pengujian debit air bertujuan untuk mengetahui seberapa banyak air yang mengalir dalam satuan volume per satuan waktu. Besarnya nilai dari debit air dapat dihitung dengan persamaan 2 berikut ini :

$$
\text { Debit }=\frac{\text { Volume bejana }}{\text { Waktu untuk memenuhi bejana }}
$$

$$
\begin{aligned}
\text { Debit }= & \frac{220 \text { liter }}{31} \\
& =7,1 \text { liter } / \mathrm{s} \\
& =0,0071 \mathrm{~m}^{3} / \mathrm{s}
\end{aligned}
$$

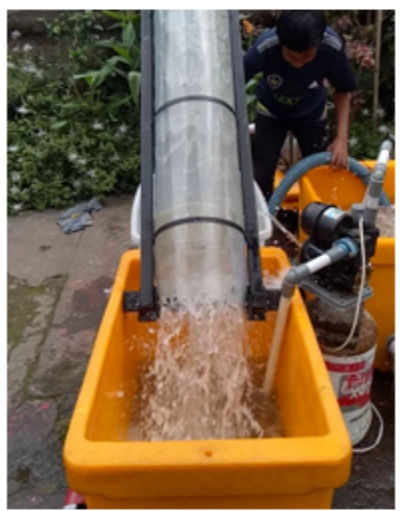

Gambar 8: Pengukuram Debit Air

Pada perhitungan di atas merupakan hasil dari pengukuran debit air, berdasarkan hasil perhitungan dapat diketahui debit air diatas merupakan debit air yang terbaik .

\section{A. Pengukuran Putaran Turbin}

Pengukuran putaran turbin ini bertujuan untuk mengetahui berapa putaran Turbin sebelum dan setelah dikopel dengan generator. Alat yang digunakan untuk mengukur putaran turbin ini yaitu menggunakan tachometer yang ditempelkan pada rotor turbin.

I Kadek Agus Adika : Analisa Pengaruh Jarak Sudu ....

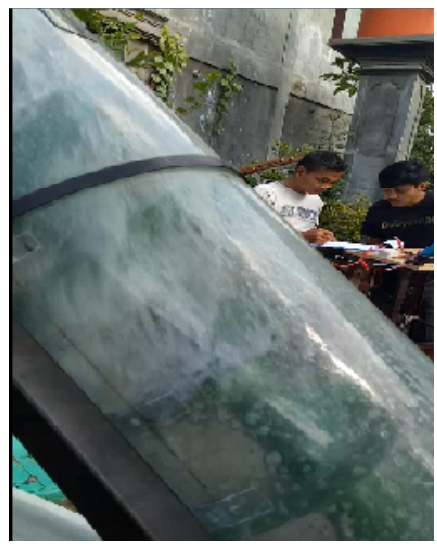

Gambar 9: Pengukuran Putaran Turbin dan Putaran Generator

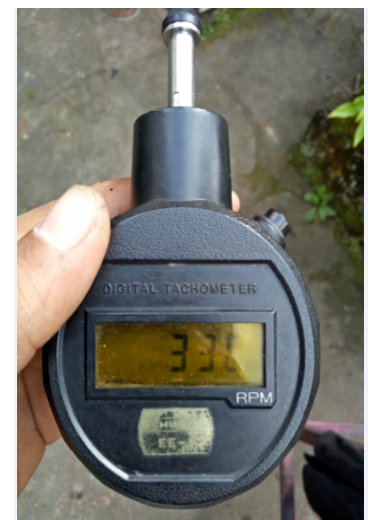

\begin{tabular}{|c|c|c|c|c|}
\hline \multirow{2}{*}{ No } & \multirow{2}{*}{ Jarak Blade } & \multirow{2}{*}{ Sudut Turbin } & \multicolumn{2}{|c|}{ Putaran Turbin (rpm) } \\
\hline & & & Sebelum dikopel & Setelah dikopel \\
\hline \multirow{5}{*}{1} & \multirow{5}{*}{$18 \mathrm{~cm}$} & \multirow{5}{*}{$28^{\circ}$} & 330 & 216 \\
\hline & & & 331 & 214 \\
\hline & & & 330 & 217 \\
\hline & & & 332 & 216 \\
\hline & & & 331 & 216 \\
\hline \multirow{5}{*}{2} & \multirow{5}{*}{$22 \mathrm{~cm}$} & \multirow{5}{*}{$28^{\circ}$} & 585 & 315 \\
\hline & & & 587 & 317 \\
\hline & & & 588 & 318 \\
\hline & & & 589 & 319 \\
\hline & & & 590 & 321 \\
\hline \multirow{5}{*}{3} & \multirow{5}{*}{$25 \mathrm{~cm}$} & \multirow{5}{*}{$28^{\circ}$} & 583 & 314 \\
\hline & & & 581 & 302 \\
\hline & & & 580 & 311 \\
\hline & & & 582 & 302 \\
\hline & & & 584 & 308 \\
\hline
\end{tabular}

Gambar 10: Hasil Penunjukan Pengukuran Putaran Turbin

TABEL II

PENGUKURAN PUTARAN TURBIN

p-ISSN:1693 - 2951; e-ISSN: 2503-2372 
Jarak $22 \mathrm{~cm}$ dengan kemiringan sudut blade $28^{0}$ pada saat pengujian hasil putaran yang dihasilkan merupakan hasil tertinggi dengan kecepatan $589 \mathrm{rpm}$ pada saat tidak dikopel dan 318 rpm pada saat turbin di kopel, lengkungan dan jarak blade yang dihasilkan juga baik dialiri air sehingga turbin dapat berputar dengan baik, dan jarak blade $25 \mathrm{~cm}$ dengan kemiringan sudut blade $28^{\circ}$ mengalami peningkatan putaran setelah dilakukan perubahan kemiringan sudut bladenya hasil pengukuran menunjukan $307 \mathrm{rpm}$, pada posisi jarak blade $25 \mathrm{~cm}$ dengan kemiringan sudut $31^{\circ}$ putaran turbin pada saat dilakukan pengujian menunjukan hasil pengukuran 287 rpm, kenaikan kecepatan di karenakan perubahaan bentuk blade yang sebelumnya $31^{0}$ menjadi $28^{\circ}$ membuat lengkungan blade menjadi lengkung berbeda dengan kemringan sudut blade $31^{0}$ mengakibatkan air banyak keluar dan membuat turbin kurang maksimal untuk berputar.

\section{B. Pengukuran dan Perhitungan Putaran Generator}

Putaran generator terjadi pada saat gear pada rotor turbin dikopel dengan gear yang dipasangpada rotor generator. Setelah dialirkan air pada turbin maka gear pada turbin akan berputar, sehingga gear pada generator ikut berputar. Pengujian putaran generator bertujuan untuk mengetahui kecepatan putaran (rpm) generator, Padapengukuran putaran generator dilakukan dengan cara menempelkan tachometer pada rotor generator.

TABELIII

PENGUKURAN PUTARAN GENERATOR

\begin{tabular}{|c|c|c|c|}
\hline No & Jarak Blade & Sudut Turbin & Putaran generator (rpm) \\
\hline \multirow{5}{*}{1} & \multirow{5}{*}{$18 \mathrm{~cm}$} & \multirow{5}{*}{$28^{\circ}$} & 3960 \\
\hline & & & 3972 \\
\hline & & & 3960 \\
\hline & & & 3984 \\
\hline & & & 3972 \\
\hline \multirow{5}{*}{2} & \multirow{5}{*}{$22 \mathrm{~cm}$} & \multirow{5}{*}{$28^{\circ}$} & 7020 \\
\hline & & & 7044 \\
\hline & & & 7056 \\
\hline & & & 7068 \\
\hline & & & 7084 \\
\hline \multirow{5}{*}{3} & \multirow{5}{*}{$25 \mathrm{~cm}$} & \multirow{5}{*}{$28^{\circ}$} & 6996 \\
\hline & & & 6972 \\
\hline & & & 6980 \\
\hline & & & 6984 \\
\hline & & & 7008 \\
\hline \multirow{5}{*}{4} & \multirow{5}{*}{$18 \mathrm{~cm}$} & \multirow{5}{*}{$24^{\circ}$} & 4643 \\
\hline & & & 4542 \\
\hline & & & 4573 \\
\hline & & & 4574 \\
\hline & & & 4576 \\
\hline \multirow{5}{*}{6} & \multirow{5}{*}{$25 \mathrm{~cm}$} & \multirow{5}{*}{$31^{\circ}$} & 6708 \\
\hline & & & 6732 \\
\hline & & & 6744 \\
\hline & & & 6744 \\
\hline & & & 6780 \\
\hline
\end{tabular}

Berdasarkan tabel IIIdapat dilihat bahwa perbandingan putaran generator dari jarak blade $18 \mathrm{~cm}$ dengan kemiringan sudut blade $24^{0}$ pada saat pengukuran menunjukan hasil putaran $4582 \mathrm{rpm}$ dan pada jarak blade $18 \mathrm{~cm}$ dengan kemiringan sudut blade $28^{\circ}$ mengalami penurunan pada saat pengujuan atau pengukuran pada jarak blade tersebut menunjukan hasil 3969 rpm karena putaran turbin yang telah dikopel menunjukan hasil pengukuran yang kecil, untuk jarak blade $21 \mathrm{~cm}$ dengan kemiringan blade $28^{0}$ menunjukan hasil pengujian kecepatan generator $7054 \mathrm{rpm}$ kecepatan generator ini yang terbaik, sedangkan turbin dengan jarak blade $25 \mathrm{~cm}$ dengan kemiringan sudut blade $31^{\circ}$ menunjukan hasil pengkuran $6742 \mathrm{rpm}$, pengujian dilakukan merubah kemiringan sudut turbin dari $31^{\circ}$ menjadi $28^{\circ}$ dengan jarak yg sama pada pengujian putaran generator yg di hasilkan 6988 rpm meningkat dari turbin dengan sudut kemiringan $31^{0}$.

\section{Pengukuran Tegangan,Arus, Daya Generator}

Pengukuran tegangan ini menggunakan alat ukur Multimeter digital, tujuan pengukuran tegangan pada pemodelan pembangkit listrik tenaga mikrohidroini bertujuan untuk mengetahui berapa tegangan output yang dikeluarkan oleh generator setelah dikopel dengan turbin pada pemodelan PLTMH yang dibuat. generator ini diberikan tekanan air 24 psi untuk memutar turbin yang sudah dikopel dengan generator.

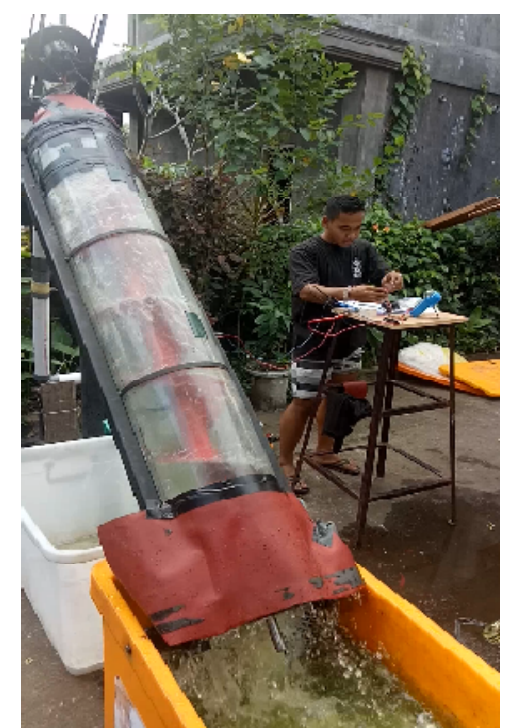

Gambar 11: Gambar pengukuran Tegangan, Arus, Daya pada Generator

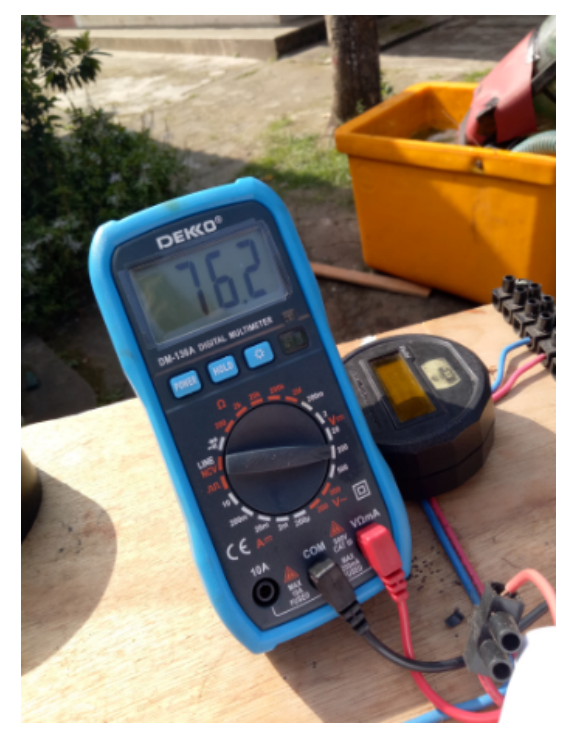

Gambar 12: Penunjukan Hasil pengukuran Tegangan, Arus, Daya pada Generator 
TABEL IV

PENGUKURAN TEGANGAN GENERATOR

\begin{tabular}{|c|c|c|c|c|}
\hline \multirow{2}{*}{ No } & \multirow{2}{*}{ Jarak Blade } & \multirow{2}{*}{ Sudut blade } & \multicolumn{2}{|c|}{ Tegangan Generator (V) } \\
\hline & & & Tanpa Beban & Berbeban 60 watt \\
\hline \multirow{5}{*}{1} & \multirow{5}{*}{$18 \mathrm{~cm}$} & \multirow{5}{*}{$28^{\circ}$} & 91,7 & 70,8 \\
\hline & & & 91,1 & 70,7 \\
\hline & & & 91,2 & 70,2 \\
\hline & & & 91,1 & 70,4 \\
\hline & & & 91,2 & 70,9 \\
\hline \multirow{5}{*}{2} & \multirow{5}{*}{$22 \mathrm{~cm}$} & \multirow{5}{*}{$28^{\circ}$} & 162,5 & 129,1 \\
\hline & & & 162,5 & 129,2 \\
\hline & & & 162,7 & 129,3 \\
\hline & & & 162,8 & 129,5 \\
\hline & & & 163,8 & 129,7 \\
\hline \multirow{5}{*}{3} & \multirow{5}{*}{$25 \mathrm{~cm}$} & \multirow{5}{*}{$28^{\circ}$} & 132,4 & 106,6 \\
\hline & & & 132,5 & 106,3 \\
\hline & & & 132,4 & 106,9 \\
\hline & & & 132,3 & 106,2 \\
\hline & & & 132,8 & 106,5 \\
\hline \multirow{5}{*}{4} & \multirow{5}{*}{$18 \mathrm{~cm}$} & \multirow{5}{*}{$24^{\circ}$} & 105,0 & 81,2 \\
\hline & & & 106,2 & 82,3 \\
\hline & & & 105,3 & 81,8 \\
\hline & & & 105,4 & 81,9 \\
\hline & & & 106,4 & 81,9 \\
\hline \multirow{5}{*}{6} & \multirow{5}{*}{$25 \mathrm{~cm}$} & \multirow{5}{*}{$31^{\circ}$} & 125,9 & 100,0 \\
\hline & & & 125,2 & 100,3 \\
\hline & & & 125,6 & 100,5 \\
\hline & & & 125,8 & 100,6 \\
\hline & & & 125,9 & 100,9 \\
\hline
\end{tabular}

Berdasarkan tabel IV dapat dilihat bahwa tegangan pada ketiga turbin dengan tekanan air 24 psi menunjukan hasil pengujian yang berbeda, hasil torsi tertinggi ditunjukan oleh turbin dengan jarak $22 \mathrm{~cm}$ dengan kemiringan sudut $28^{\circ}$, dalam pengujian ada dua turbin yang dirubah kemiringan sudutnnya di karenakan sudut $28^{\circ}$ itu ialah hasil pengukuran tertinggi maka, dilakakukan perubahan pada turbin dengan jarak blade $18 \mathrm{~cm}$ dengan sudut yang berbeda dengan tekanan air yang sama yaitu 24 psi , pada sudut $24^{0}$ tegangan hasil pengukuran menunjukan 105,7 Volt tanpa beban dan berbeban 81,8 Volt dan setelah melakukan perubahan kemiringan sudut menjadi $28^{0}$ tegangan menjadi menurun pada pengukuran menunjukan hasil 91.3 Volt tanpa beban dan 70, 6 Volt dalam keadaan kondisi berbeban. Penurununan itu terjadi karena putaran turbin tidak maksimal membuat putaran generator melambat.

\section{Pengukuran Arus Generator}

Pengukuran arus generator pada pemodelan pembangkit listrik tenaga mikrohidro ini bertujuan untuk mengetahui berapa arus yang dihasilkan masing-masing turbin dengan jarak yang berbeda jika dikopel dengan generator, pengukuran arus pada pemodelan pembangkit listrik tenaga mikrohidro ini menggunakan beban sebesar 60 watt dengan alat ukur yang digunakan adalah alat ukur multimeter digital. Dalam pengukuran arus generator ini diberikan tekanan air 24 psiuntuk memutar turbin yang sudah dikopel dengan generator.
TABELV

PENGUKURAN ARUS GENERATOR

\begin{tabular}{|c|c|c|c|c|}
\hline \multirow{2}{*}{ No } & \multirow{2}{*}{ Jarak Blade } & \multirow{2}{*}{ Sudut blade } & \multicolumn{2}{|c|}{ Arus Generator (A) } \\
\hline & & & Tanpa Beban & Berbeban 60 watt \\
\hline \multirow{5}{*}{1} & \multirow{5}{*}{$18 \mathrm{~cm}$} & \multirow{5}{*}{$28^{\circ}$} & 0 & 0.1440 \\
\hline & & & 0 & 0,1442 \\
\hline & & & 0 & 0,1441 \\
\hline & & & 0 & 0,1442 \\
\hline & & & 0 & 0,1444 \\
\hline \multirow{5}{*}{2} & \multirow{5}{*}{$22 \mathrm{~cm}$} & \multirow{5}{*}{$28^{\circ}$} & 0 & 0,1773 \\
\hline & & & 0 & 0,1773 \\
\hline & & & 0 & 0,1774 \\
\hline & & & 0 & 0,1775 \\
\hline & & & 0 & 0,1777 \\
\hline \multirow{5}{*}{3} & \multirow{5}{*}{$25 \mathrm{~cm}$} & \multirow{5}{*}{$28^{\circ}$} & 0 & 0,1759 \\
\hline & & & 0 & 0,1754 \\
\hline & & & 0 & 0,1757 \\
\hline & & & 0 & 0,1753 \\
\hline & & & 0 & 0,1758 \\
\hline \multirow{5}{*}{4} & \multirow{5}{*}{$18 \mathrm{~cm}$} & \multirow{5}{*}{$24^{\circ}$} & 0 & 0,1546 \\
\hline & & & 0 & 0,1557 \\
\hline & & & 0 & 0,1567 \\
\hline & & & 0 & 0,1567 \\
\hline & & & 0 & 0,1578 \\
\hline \multirow{5}{*}{6} & \multirow{5}{*}{$25 \mathrm{~cm}$} & \multirow{5}{*}{$31^{\circ}$} & 0 & 0,1737 \\
\hline & & & 0 & 0,1739 \\
\hline & & & 0 & 0,1738 \\
\hline & & & 0 & 0,1738 \\
\hline & & & 0 & 01732 \\
\hline
\end{tabular}

Berdasarkan tabel $\mathrm{V}$ dapat dilihat bahwa perbandingan pengaruh jarak blade antara turbin berjarak $18 \mathrm{~cm}$ dengan kemiringan sudut blade $28^{0}$, jarak blade $22 \mathrm{~cm}$ dengan kemiringan sudut blade $28^{\circ}$, dan jarak blade $25 \mathrm{~cm}$ dengan kemiringan sudut blade $28^{\circ}$, untuk membandingkan hasil pengukuran menggunakan turbin dengan jarak blade yang sama tetapi sudut kemiringan blade nya berbeda yaitu $24^{0}, 28^{0}$, $31^{\circ}$, hasil pengukuran menunjukan perbedaan arus yang terjadi pada jarak blade $18 \mathrm{~cm}$ dengan sudut kemiringan blade $24^{0}$ hasil pengukuran, $1563 \mathrm{~A}$, untuk jarak blade $18 \mathrm{~cm}$ dengan kemiringan blade $28^{\circ}$ mengalamipenurunan arus, pada saat pengukuran didapatkan hasil 0,1441A di karenakan puataran turbin yang menurun serta perubahan kemiringan sudut blade dari $24^{0}$ menjadi $28^{0}$ sehingga membuat sudut blade menjadi terbuka air yang mengalir pada blade-bladenya kurang sempurna dengan jarak yang kurang panjang ialah berjarak 18 $\mathrm{cm}$.

\section{E. Perhutungan Daya Generator}

Pengukuran daya generator pada pemodelan pembangkit listrik tenaga mikrohidro dengan menggunakan turbin Archimedes screw dengan jarak blade $18 \mathrm{~cm}$ dengan sudut kemiringan blade $24^{0}$, jarak blade $22 \mathrm{~cm}$ dengan sudut kemiringan blade $28^{\circ}$, jarak blade $25 \mathrm{~cm}$ dengan sudut kemiringan blade $31^{\circ}$ dan jarak blade $18 \mathrm{~cm}$ dengan sudut kemiringan blade $28^{0}, 22 \mathrm{~cm}$ dengan sudut kemiringan blade $28^{0}, 25 \mathrm{~cm}$ dengan sudut kemiringan blade $28^{0}$ ini bertujuan untuk mengetahui daya yang dikeluarkan oleh generator setelah dikopel dengan turbin. 
TABELVI

PERHITUNGAN DAYA GENERATOR

\begin{tabular}{|c|c|c|c|c|}
\hline \multirow{2}{*}{ No } & \multirow{2}{*}{ Jarak Blade } & \multirow{2}{*}{ Sudut blade } & \multicolumn{2}{|c|}{ Daya (Watt) } \\
\hline & & & Tanpa Beban & Berbeban 60 watt \\
\hline \multirow{5}{*}{1} & \multirow{5}{*}{$18 \mathrm{~cm}$} & \multirow{5}{*}{$28^{\circ}$} & 0 & 10,2 \\
\hline & & & 0 & 10,2 \\
\hline & & & 0 & 10,1 \\
\hline & & & 0 & 10,2 \\
\hline & & & 0 & 10,2 \\
\hline \multirow{5}{*}{2} & \multirow{5}{*}{$22 \mathrm{~cm}$} & \multirow{5}{*}{$28^{\circ}$} & 0 & 22,9 \\
\hline & & & 0 & 22,9 \\
\hline & & & 0 & 22,9 \\
\hline & & & 0 & 22,9 \\
\hline & & & 0 & 23 \\
\hline \multirow{5}{*}{3} & \multirow{5}{*}{$25 \mathrm{~cm}$} & \multirow{5}{*}{$28^{\circ}$} & 0 & 18,7 \\
\hline & & & 0 & 18,6 \\
\hline & & & 0 & 18,8 \\
\hline & & & 0 & 18,6 \\
\hline & & & 0 & 18,7 \\
\hline \multirow{5}{*}{4} & \multirow{5}{*}{$18 \mathrm{~cm}$} & \multirow{5}{*}{$24^{\circ}$} & 0 & 12,6 \\
\hline & & & 0 & 12,8 \\
\hline & & & 0 & 12,8 \\
\hline & & & 0 & 12,8 \\
\hline & & & 0 & 12,9 \\
\hline \multirow{5}{*}{6} & \multirow{5}{*}{$25 \mathrm{~cm}$} & \multirow{5}{*}{$31^{\circ}$} & 0 & 17,3 \\
\hline & & & 0 & 17,4 \\
\hline & & & 0 & 17,5 \\
\hline & & & 0 & 17,5 \\
\hline & & & 0 & 17.5 \\
\hline
\end{tabular}

Berdasarkan tabel VI dapat dilihat bahwa perbandingan daya dengan pengaruh jarak blade antara turbin berjarak 18 $\mathrm{cm}$ dengan kemiringan sudut blade $28^{0}$, jarak blade $22 \mathrm{~cm}$ dengan kemiringan sudut blade $28^{\circ}$, dan jarak blade $25 \mathrm{~cm}$ dengan kemiringan sudut blade $28^{\circ}$, untuk membandingkan hasil pengukuran menggunakan turbin dengan jarak blade yang sama tetapi sudut kemiringan blade nya berbeda yaitu $24^{0}, 28^{0}, 31^{0}$, hasil pengukuran menunjukan perbedaan daya yang terjadi pada jarak blade $18 \mathrm{~cm}$ dengan sudut kemiringan blade $24^{0}$ hasil pengukuran 12,8 Watt , untuk jarak blade 18 $\mathrm{cm}$ dengan kemiringan blade $28^{0}$ mengalamipenurunan daya , pada saat pengukuran didapatkan hasil 10,8 Watt, di karenakan puataran turbin yang menurun serta perubahan kemiringan sudut blade dari $24^{\circ}$ menjadi $28^{\circ}$ sehingga sudut blade menjadi terbuka air yang mengalir pada blade-bladenya kurang sempurna dan jarak yang pendek membuat aliran air semakin cepat berpindah dari blade 1 ke blade lainnya, membuat hasil kali antara Arus dan Tegangan menjadi menurun karena perubahan kemiringan sudut blade .

\section{F. Perhitungan Daya Hidrolis}

Pada pengukuran yang dilakukan pada pengujian PLTMH dengan input tekanan air yang berbeda-beda ini maka akan didapatkan daya hidrolis. Daya hidrolis adalah daya yang dihasilkan oleh air yang mengalir. Berikut ini adalah perhitungan daya hidrolis dengan menggunakan persamaan 1 :

Adapun hasil perhitungan daya hidrolis

$P=1000 \times 9,81 \times 0,0071 \times 1,34=93,3$ Watt

Berdasarkan perhitungan dapat dilihat bahwa, dimana daya hidrolis ini dipengaruhi oleh head atau tinggi air yang jatuh. Sehingga semakin tinggi head dan massa fluida yang beasr, serta di pengaruhi oleh gaya gravitasi membuat aliran debit air menghasilkan tekanan gaya dorong yang tinggi untuk mendapatkan daya hidrolis yang besar.

\section{G. Perhitungan Efisiensi Pada Pemodelan PLTMH \\ Menggunakan Turbin Archimedes Screw}

Pada pengukuran yang dilakukan pada pengujian pembangkit listrik tenaga mikro hidro dengan input tekanan air 24 psimaka akan didapatkan efisiensi dari sistem pemodelan pembangkit listrik tenaga mikro hidro menggunakan 3 turbin Archimedes screw. Berikut ini adalah perhitungan efisiensi yang diperoleh dari daya output dibagi dengan daya input sesuai persamaan 3 .

TABELVII

PERHITUNGAN EFISIENSI PLTMH

\begin{tabular}{|c|c|c|c|c|c|}
\hline No & $\begin{array}{c}\text { Tekanan } \\
\text { (psi) }\end{array}$ & $\begin{array}{c}\text { Jarak (cm) dan } \\
\text { Sudut ( })\end{array}$ & $\begin{array}{c}\text { Daya } \\
\text { Generator } \\
\text { (Watt) }\end{array}$ & $\begin{array}{c}\text { Daya } \\
\text { Hidrolis } \\
\text { (Watt) }\end{array}$ & $\begin{array}{c}\text { Efisiensi } \\
\text { sistem } \\
\text { PLTMH (\%) }\end{array}$ \\
\hline 1 & 24 & $18 \mathrm{cmdan} 28^{\circ}$ & 10,8 & 93.3 & 11,6 \\
\hline 2 & 24 & $22 \mathrm{~cm} \mathrm{dan} \mathrm{28^{ \circ }}$ & 22,9 & 93.3 & 24,5 \\
\hline 3 & 24 & $25 \mathrm{~cm}$ dan $28^{\circ}$ & 18,8 & 93.3 & 20,4 \\
\hline 4 & 24 & $18 \mathrm{~cm}$ dan $24^{\circ}$ & 12,8 & 93.3 & 13,7 \\
\hline 5 & 24 & $25 \mathrm{~cm}$ dan $31^{\circ}$ & 17,6 & 93,3 & 18,6 \\
\hline
\end{tabular}

Berdasarkan tabel VII dapat dilihat bahwa efisiensi pada ketiga turbin dengan tekanan air 24 psi menunjukan hasil pengujian yang berbeda, hasil efisenis tertinggi ditunjukan oleh turbin dengan jarak $22 \mathrm{~cm}$ dengan kemiringan sudt $28^{\circ}$, dalam pengujian ini ada dua turbin yang dirubah kemiringan sudutnnya di karenakan sudut $28^{0}$ itu ialah hasil pengukuran tertinggi maka, dilakakukan perubahan pada turbin dengan jarak $18 \mathrm{~cm}$ dengan sudut yang berbeda dengan tekanan air yang sama yaitu 24 psi , pada sudut $24^{0}$ efisiensi hasil perhitungan menunjukan $18,1 \%$ dan setelah melakukan perubahan kemiringan sudut menjadi $28^{0}$ efisiensi menjadi menurun pada perhitungan menunjukan hasil $11,6 \%$.

\section{H. Perhitungan Torsi pada Pemodelan}

PLTMH

\section{Menggunakan Turbin Archimedes Screw}

Pengukuran yang dilakukan pada pengujian pembangkit listrik tenaga mikro hidro dengan input tekanan air 24 psi dan dengan menggunakan 3 buah turbin dengan jarak antar bladebladenya berbeda dan kemringingan sudut yang di rubah, maka akan didapatkan torsi turbin saat dikopel dengan generator dapat dilihat pada perhitungan dibawah ini sesuai dengan persamaan 4 .

TABELVIII

PERHITUNGAN TORSI PLTMH

\begin{tabular}{|c|c|c|c|c|}
\hline No & $\begin{array}{c}\text { Jarak } \\
(\mathbf{c m})\end{array}$ & Sudut & $\begin{array}{c}\text { Tekanan } \\
\text { (psi) }\end{array}$ & $\begin{array}{c}\text { Torsi } \\
(\mathbf{N m})\end{array}$ \\
\hline 1 & 18 & $28^{\circ}$ & 24 & 0,47 \\
\hline 2 & 22 & $28^{\circ}$ & 24 & 0,68 \\
\hline 3 & 25 & $28^{\circ}$ & 24 & 0,58 \\
\hline 4 & 18 & $24^{\circ}$ & 24 & 0,55 \\
\hline 5 & 25 & $31^{\circ}$ & 24 & 0,57 \\
\hline
\end{tabular}

Berdasarkan tabel VIII dapat dilihat bahwa torsi pada ketiga turbin dengan tekanan air 24 psi menunjukan hasil 
pengujian yang berbeda, hasil torsi tertinggi ditunjukan oleh turbin dengan jarak $22 \mathrm{~cm}$ dengan kemiringan sudut $28^{\circ}$, dalam pengujian ada dua turbin yang dirubah kemiringan sudutnnya di karenakan sudut $28^{\circ}$ itu ialah hasil pengukuran tertinggi maka, dilakakukan perubahan pada turbin dengan jarak blade $18 \mathrm{~cm}$ dengan sudut yang berbeda dengan tekanan air yang sama yaitu 24 psi, pada sudut $24^{0}$ torsi hasil perhitungan menunjukan $0,552 \mathrm{Nm}$ dan setelah melakukan perubahan kemiringan sudut menjadi $28^{0}$ torsi menjadi menurun pada perhitungan menunjukan hasil 0,478 $\mathrm{Nm}$. Penurunan itu terjadi karena putaran turbin tidak maksimal membuat putaran generator melambat.

\section{Rata-rata Hasil Pengukuran}

Hasil pengukuran dari parameter yang telah diukur pada pemodelan PLTMH ini dapat dilihat pada tabel

\section{TABEL IX}

RATA-RATA PENGUKURAN DAN PERHITUNGAN PLTMH

\begin{tabular}{|c|c|c|c|c|c|c|c|c|c|c|}
\hline \multirow[t]{2}{*}{$\begin{array}{c}\text { Jarak } \\
\text { Turbin }\end{array}$} & \multirow[t]{2}{*}{$\begin{array}{l}\text { Sudut } \\
\text { turbin }\end{array}$} & \multicolumn{2}{|c|}{$\begin{array}{l}\text { Putaran Turbin } \\
\text { (rpm) }\end{array}$} & \multirow{2}{*}{$\begin{array}{l}\text { Putaran } \\
\text { Generator } \\
(\mathrm{pm})\end{array}$} & \multicolumn{3}{|c|}{ Tampa Beban } & \multicolumn{3}{|c|}{ Beban } \\
\hline & & $\begin{array}{l}\text { Sebelum } \\
\text { dikopel }\end{array}$ & $\begin{array}{l}\text { Setelah } \\
\text { dikopel }\end{array}$ & & $\begin{array}{c}\text { Tegangan } \\
\text { (I) }\end{array}$ & \begin{tabular}{|l} 
Arus \\
(I)
\end{tabular} & $\begin{array}{c}\text { Dayg } \\
\text { (P) }\end{array}$ & $\begin{array}{l}\text { Tegangan } \\
\text { (I) }\end{array}$ & $\begin{array}{l}\text { Arus } \\
\text { (I) }\end{array}$ & $\begin{array}{c}\text { Daya } \\
\text { (P) }\end{array}$ \\
\hline $18 \mathrm{~cm}$ & $28^{\circ}$ & 331 & 216 & 3969 & 91.3 & 0 & 0 & 70,6 & 0.1441 & 10.8 \\
\hline $22 \mathrm{~cm}$ & $28^{\circ}$ & 589 & 318 & 7054 & 162,7 & 0 & 0 & 129,4 & 0,1774 & 22,9 \\
\hline $25 \mathrm{~cm}$ & $28^{9}$ & 582 & 307 & 6988 & 132,5 & 0 & 0 & 106,5 & 0,1756 & 18,7 \\
\hline $18 \mathrm{~cm}$ & $24^{\circ}$ & 383 & 222 & 4582 & 105,7 & 0 & 0 & 81,8 & 0,1563 & 12,8 \\
\hline $22 \mathrm{~cm}$ & $28^{\circ}$ & 589 & 318 & 7054 & 162,7 & 0 & 0 & 129,4 & 0,1774 & 22,9 \\
\hline $25 \mathrm{~cm}$ & $31^{\circ}$ & 562 & 287 & 6742 & 125.9 & 0 & 0 & 100,5 & 0.1737 & 17,4 \\
\hline
\end{tabular}

J. Perhitungan Jarak Blade, Kemiringan sudut Blade, dan Jumlah BladePada Pemodelan PLTMH Menggunakan Turbin Archimedes Screw

Posisi jarak antar balde turbin ulir pada pemodelan pembangkit listrik tenaga mikro hidro ini dapat di hitung dalam persamaan 5, 6 dan 7, perhitungan jarak blade sangat berpengaruh terhadap nilai dari parameter- parameter yang diukur.

TABELX

PERHITUNGAN JARAK BLADE, SUDUT BLADE, JUMLAH BLADE PADA TURBIN ARCHIMEDES

\begin{tabular}{|c|c|c|c|}
\hline No & $\begin{array}{c}\text { Jarak } \\
(\mathbf{c m})\end{array}$ & Sudut Blade & Jumlah Blade \\
\hline 1 & 16 & $22^{\circ}$ & 9,3 \\
\hline 2 & 17 & $23^{\circ}$ & 8,8 \\
\hline 3 & 18 & $24^{\circ}$ & 8,3 \\
\hline 4 & 19 & $25^{\circ}$ & 7,9 \\
\hline 5 & 20 & $26^{\circ}$ & 7,5 \\
\hline 6 & 21 & $27^{\circ}$ & 7,1 \\
\hline 7 & 22 & $28^{\circ}$ & 6,8 \\
\hline 8 & 23 & $29^{\circ}$ & 6,5 \\
\hline 9 & 24 & $30^{\circ}$ & 6,25 \\
\hline 10 & 25 & $31^{\circ}$ & 6 \\
\hline 11 & 25,5 & $32^{\circ}$ & 5,9 \\
\hline 12 & 26 & $33^{\circ}$ & 5,7 \\
\hline
\end{tabular}

I Kadek Agus Adika : Analisa Pengaruh Jarak Sudu ....

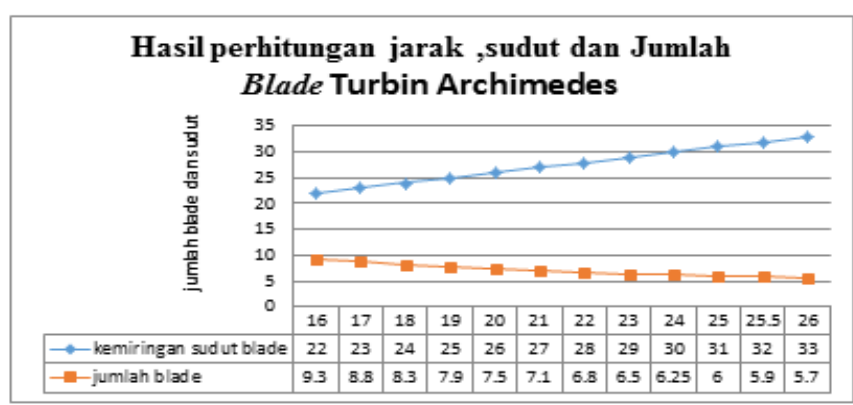

Gambar 13Grafik hasil Perhitungan jarak Blade, Sudut Blade, Jumlah Blade pada turbin Archimedes

Berdasarkan tabel $\mathrm{X}$ dan gambar 13 dapat dilihat bahwa hasil perhitungan jarak blade, sudut blade, dan jumlah blade semakin panjang jarak maka kemiringan sudut blade semakin besar dan sebaliknya jumlah blade pada turbin Archimedes berkurang, pada pemodelan pembangkit Listrik Tenaga Mikro Hidro (PLTMH) ini menggunakan 3 buah turbin dengan jarak blade dari $18 \mathrm{~cm}$ kemiringan sudut blade $24^{0}$ dengan panjang poros $150 \mathrm{~cm}$ dengan jumlah 8 buah blade, jarak $22 \mathrm{~cm}$ kemiringan sudut blade $28^{\circ}$ dengan panjang poros $150 \mathrm{~cm}$ dengan jumlah 7 buah blade, dan jarak $25 \mathrm{~cm}$ kemiringan sudut blade $31^{\circ}$ dengan panjang poros $150 \mathrm{~cm}$ dengan jumlah 6 buah blade di karenakan perhitungan secara teori dengan pembuatan alat mudah di realisasikan mengingat selisih dari perhitungan sangat sedikit dan mudah melakukan pembentukan.

\section{KESIMPULAN}

Simpulan yang dapat diambil berdasarkan hasil dari pengujian dan pembahasan yang telah dilakukan adalah sebagai berikut :

1. Pengujian perubahan jarak blade dengan tekanan air 24 psi pada pemodelan pembangkit listrik tenaga mikro hidro menggunakan turbin Archimedes screw ini, didapatkan nilai hasil pengukuran terbaik pada jarak blade $21 \mathrm{~cm}$ dengan kemiringan sudut $28^{0}$, dimana tegangan, arus, dan daya output yang dihasilkan generator yaitu sebesar 129,4 Volt berbeban 60 Watt, tanpa beban 162,7 Volt, arus yang dihasilkan 0,1774 Ampere dan daya yang dihasilkan 22,9 Watt. Untuk kecepatan putaran generator yaitu sebesar 7054 rpm, sedangkan kecepatanputaran turbin yang dihasilkan pada tekanan yaitu sebesar 589 rpm sebelum dikopel dengan generator dan $318 \mathrm{rpm}$ setelah dikopel dengan generator.

2. Efisiensi terbesar yang diperoleh pada pengujian pemodelan PLTMH ini adalah pada jarak blade $22 \mathrm{~cm}$ dengan kemiringan sudut 280 yaitu sebesar 24,5\%, sedangkan efisiensi terendah terjadi pada jarak blade 18 $\mathrm{cm}$ dengan kemiringan sudut blade $28^{0}$ yaitu sebesar $11,6 \%$. Peningkatan dan penurunan efisiensi dikarenakan jumlah blade, jarak blade, dan kemiringan sudut blade semakin panjang jarak blade air yang mengalir semakin lama air memutar blade dan sebaliknya semakin pendek jarak blade dengan sudut yang lebih besar maka air banyak yang keluar dari sirip 
blade dan langsung mengalir ke talang turbin sehingga putaran turbin tidak menjadi maksimal.

3. Torsi yang dihasilkan pada pengujian pemodelan PLTMH dengan melakukan perubahan jarak blade dengan tekanan air 24 psi menyebabkan torsi yang dihasilkan berbeda-beda. Berdasarkan hasil pengujian, maka untuk menghasilkan torsi yang mampu memutar generator agar generator dapat menghasilkan tegangan, arus, dan daya yang besar pada pemodelan PLTMH dengan menggunakan 3 turbin yang berbeda ini adalah dengan menggunakan turbin dengan jarak blade $22 \mathrm{~cm}$ dengan kemiringan sudut blade. Torsi yang dihasilkan pada saat pengujian yaitu sebesar $0,68 \mathrm{Nm}$.

\section{REFERENSI}

[1] Bahri, A,. 2017. Merancang dan Mengimplementasikan Modul Praktikum Pembangkit Listrik Tenaga Mikro Hidro di Jurusan Teknik Elektro dan Komputer Universitas Udayana Majalah Ilmiah Teknologi Elektro, Vol. 16, (Mei - Agustus ) : 43-47

[2] Saroinsing, T., Thomas, A.Mekel, A.,N. 2017. Desain dan Pembuatan Trubin Ulir Archimedes Untuk Pembangkit Listrik Tenaga Mikro.ISSN 2447-2097. Vol. 32017 : 159-169.

[3] Saefudin, E., Kristyadi, T., Rifki,M., Arifin,S. 2017 Turbin Screw untuk Pembangkit Listrik Skala Mikrohidro Ramah Lingkungan. Jurnal Rekayasa Hijau, Vol. 1 (Oktober) 2017 : 223-244.

[4] Rorres, C. 2000. The Trun Of The Screw : Optimal Design Of AN Archimedes Screw. Journal of Hydraulic Engineering,Vol. 126 (Januari) : 72-80.

[5] Juliana, I., P., Weking, A., I., Jasa, L. 2018 Pengaruh Sudut Kemiringan Head Turbin Ulir dan Daya Putar Turbin Ulir dan Daya Output Pada Pembangkit Listrik Tenaga Mikro Hidro. Majalah Ilmiah Teknologi Elektro, Vol. 17, No. 3, (September - Desember) 2018 : 393- 400

[6] Syahputra, M.T. 2017. Rancang Bangun Prototipe Pembangkit Listrik Tenaga Piko Hidro Dengan Menggunakan Turbin Ulir. e-ISSN 22527036, Vol. 2 (Juni) : $16-22$.

[7] Havendri, A., Arnif,I. 2010. Kaji Eksperimental Penentuan Sudut Ulir Optimum Pada Turbin Ulir Untuk Data PerencanaanTurbin Ulir Pada Pusat Listrik Tenaga MikroHidro (PLTMH) Dengan Head Rendah. Seminar Tahunan Tekni kMesin (SNTTM), Vol. 9 (Oktober) : 273-277.

[8] Setiarso, M., A., Widiyanto, W., Purnomo, S., N. 2017. Potensi Tenaga Listrik dan Penggunaan Turbin Ulir Untuk Pembangkit Skla Kecil di Saluran Irigasi Banjar cahyana.p-ISSN1858-3075, Vol. 1 : 19-27.

[9] Widnyana, I., G., Weking, A., I., Jasa, L. Analisa Pengaruh Tekanan Air Terhadap Kinerja PLTMH dengan Menggunakan Turbin Archimedes Screw. Majalah Ilmiah Teknologi Elektro, Vol. 17, No. 3, (September - Desember) 2018:1- 10

[10] Wie,S.D.,AgungA.I. 2018. Perencanaan Dan Implementasi Prototipe Pembangkit Listrik Tenaga Mikro Hidro (PLTMH). JurnalTeknik Elektro, Vol.7 (Januari) : 31-36. 